\title{
Zagrebačko razdoblje Pjera Križanića
}

\author{
The Zagreb \\ Period of Pjer Križanić
}


IZVORNI ZNANSTVENI RAD

Primljen: 25. ožujka 2021.

Prihvaćen: 7. lipnja 2021.

DOI: 10.31664/zu.2021.108.05

\section{APSTRAKT}

Pjer Križanić (Glina, 19. svibnja 1890.-Beograd, 21. siječnja 1962.), karikaturist, slikar i likovni kritičar, svoj životni put i obrazovanje započeo je na rodnoj Baniji, a potom dolazi u Zagreb, gdje završava Obrtnu školu te nastavlja studirati slikarstvo na likovnoj akademiji. U Zagrebu je objavio svoje prve karikature te time započeo karijeru karikaturista. Zagrebačko razdoblje Pjera Križanića njegove su formativne godine, doba likovnog sazrijevanja i formiranja stava o karikaturi kao specifičnom načinu izražavanja. To je vrijeme kada Križanić razvija svoj prepoznatljiv rukopis i sazrijeva u svojim političkim stavovima, što sačinjava podlogu za stvaranje iznimnog opusa sadržajne, provokativne i duhovite političke karikature. Karijeru započetu u Zagrebu nastavio je u Beogradu 1922. Istraživanje zagrebačke dionice Križanićeva plodnog crtačkog opusa razmatra njegove uzore, likovne karakteristike njegova rukopisa te izražajnost i snagu političkih poruka koje u mnogim primjerima nadilaze trenutak u kojem su nastale.

\section{KLJUČNE RIJEČI}

karikatura, politička karikatura, portretna karikatura, satira, crtež, povijest novinarstva, Pjer Križanić
ORIGINAL SCIENTIFIC PAPER

Received: March 25, 2021

Accepted: June 7, 2021

DOI: 10.31664/zu.2021.108.05

SUMMARY

Pjer Križanić (born as Petar, Glina, I9th May I890-Belgrade, 2Ist January 1962), caricaturist, painter and art critic, moved in the circle of writers, artists and bohemians gathered around Matoš, who spent most of their days in cafés where the editors of certain magazines gathered. Matoš encouraged him to engage in caricature and to publish his first caricature, that of the writer Josip Kosor, in the Zagreb paper Koprive (1909). Although Križanić undeniably developed as a caricaturists and changed his artistic expression over time, this is now difficult to judge due to the small number of preserved cartoons.

Križanić's artistic role models, primarily German and French caricaturists, can be discerned from his artistic style, but confirmation can also be found in his text "O karikaturi" [On Caricature], published in I92I in the Kritika magazine. This text aptly reveals Križanić’s understanding of caricature as well as his role models on the contemporary European scene. As a relevant source of quality caricature, he cites the Munich weekly Simplicissimus, whose dozen top cartoonists were role models not only for Križanić, but for the majority of Central European caricaturists (Thomas Theodor Heine, Karl Arnold, Olaf Gulbransson, Edward Thöny, Bruno Paul, Ferdinand von Řezníček). 
Another source of Križanić's drawing role models can be found among the French caricaturists, from Daumier, through Toulouse Lautrec to Leandreu, Forain and Matoš's friend Rouveyer. Križanić's good knowledge of French caricaturists can probably be attributed to the time spent with Matoš, who knew the scene extremely well. Even the pseudonym Pjer, which Križanić accepted as his name, came from the French language. Matoš was the one who introduced the Zagreb caricaturists to the tradition and the contemporary scene of the French caricature, which nurtured a more complex drawing with a denser line structure, unlike the German tradition that was more inclined to simpler lines and clear forms of objects, characters and space, or rather to a stylization that reduced the forms to their basic features. Among the French caricaturists whom Križanić did not mention in his text on caricature, but who may have been close to him, we should mention such significant names as Félix Valloton, Jean-Louis Forain, and Caran D'Ache to some extent.

The third group of caricaturists who influenced Križanić's artistic expression were his colleagues, the Zagreb cartoonists, starting with his professor Menci Clement Crnčić, to everyone gathered in the Koprive editorial office, primarily Slavko Vereš, but also Branimir Petrović, Franjo Maixner, Ivo Režek and Bogumil Car. All three sources had a certain influence on the formation of Križanić's approach to caricature, not only in terms of the form, but also the content, and contributed to the formation of Križanić's recognizable artistic expression.

The analysis of Križanić's style reveals a clear contour line with no excessive detailing. It all comes down to essential features in equal measure: characters, objects and space. His compositions are clean, balanced and rhythmic, and the space is simplified and flat, as if he invariably wants to move away from real space, emphasizing the fact that this is actually a space of caricature and thus making it clear that he truly understands the nature of the cartoon medium. He knew how to use expressive and surreal elements in his drawings, but we should not overlook the occasional caricature from the interwar period drawn in pure art deco style.

Križanić's legacy belongs equally to the Croatian and Serbian culture, but can also be interesting for the audience beyond our borders due to its universal messages that are still relevant today.

\section{KEYWORDS}

caricature, political cartoon, caricature portrait, satire, drawing, history of journalism, Pjer Križanić 


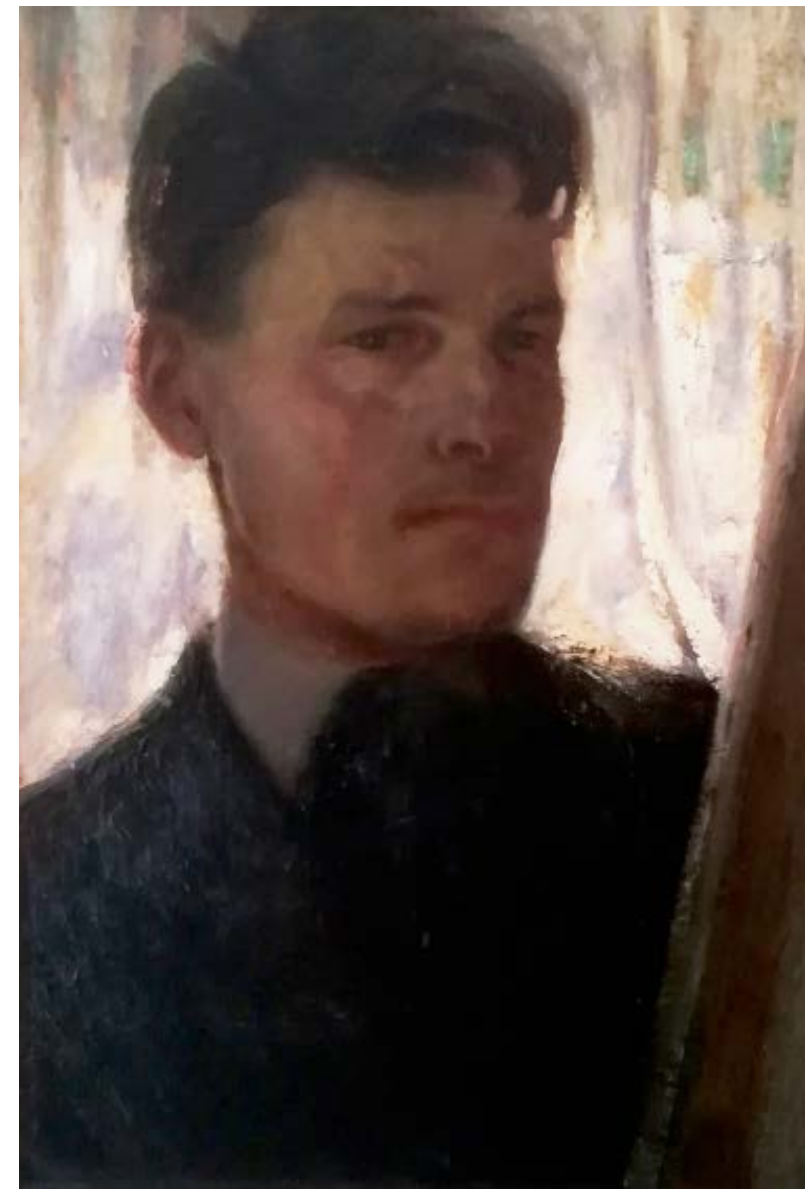

SI. 1. Pjer Križanić, Autoportret, ulje na platnu, $55,8 \times 38,3 \mathrm{~cm}$. VI. Boris Vrga. / Fig. I Pjer Križanić, Autoportrait, oil on canvas, 55,8 × 38,3 cm. Coll. Boris Vrga.
Zanimljiva ličnost Pjera Križanića, karikaturista, slikara i novinara, obilježena je dvojnošću djelovanja u Hrvatskoj i Srbiji te je svojim opusom ostavio neizbrisiv trag u obje sredine. Djetinjstvo, obrazovanje i prvi dio svojeg bogatog opusa ostvario je u Hrvatskoj, da bi potom u Srbiji postao ocem političke karikature i sudjelovao u pokretanju utjecajnog beogradskog satiričkog časopisa Ošišani jež 1935. ${ }^{1}$ S obzirom na to da je Križanić veći dio života proveo u Srbiji, njegov život, djelo i važnost posljednjih su desetljeća u toj sredini daleko više prisutni i valorizirani, što je rezultiralo i njegovom monografijom objavljenom 2010. Ipak, Križanićeva početna dionica života vezana uz Hrvatsku, od rođenja i školovanja do formiranja u jednog od istaknutih i iznimno produktivnih karikaturista, ostala je u sjeni, usprkos znatnom doprinosu Borisa Vrge, vrijednog istraživača kulturne baštine Banije, koji je rasvijetlio brojne Križanićeve biografske detalje. ${ }^{2}$ Stoga se ovaj tekst više fokusira na manje poznate činjenice te interpretaciju Križanićeva likovnog izraza u karikaturi kroz njegove uzore i sredinu u kojoj je stekao svoj prepoznatljiv karikaturalni rukopis, kao i senzibilitet za određene teme, a posebno za političku karikaturu.

Pjer Križanić, krsnim imenom Petar, rođen je u Glini 1890. Činjenica da mu je majka bila Srpkinja, a otac Hrvat odredila je mnoge okolnosti u njegovu životu. Majka mu je rano umrla, a Križanić pohađa osnovnu školu u Mečenčanima živeći kod bake po majci, Ane Rebić. Potom trošak njegova školovanja preuzima njegov ujak Stojan Rebić te ga upisuje u gimnaziju u Petrinji (1901.-1903.). Već tada njegov likovni talent uočava profesor crtanja Aleksandar Povrzanović, koji ga upućuje u Obrtnu školu u Zagreb. ${ }^{3}$ Školovanje nastavlja 1903. u Zagrebu, gdje zalaganjem svojih profesora dobiva besplatno mjesto u internatu te Obrtnu školu (dekorativno-slikarski smjer) završava 1907. Jedan od profesora bio mu je Bela Čikoš Sesija, koji je uočio njegov talent i savjetovao mu da upiše likovnu akademiju. Križanić je gotovo pune dvije godine radio je kao soboslikar kako bi s ušteđevinom 1908. upisao Privremenu višu školu za umjetnost i obrt, na kojoj je studirao do $1911 .^{4}$

\section{STUDIJ NA ZAGREBAČKOJ PRIVREMENOJ VIŠOJ ŠKOLI ZA UMJETNOST I OBRT}

„Ako je Beta (Vukanović) majka, Petar Pjer Križanić je otac naše (srpske) političke karikature.” Bojičić, Petar Križanić Pjer, 248. 2 Posljednje istraživanje biografskih podataka o Pjeru Križaniću koje je objavio Boris Vrga predstavlja znatan doprinos. Usp. Vrga, „Pjer u Zagrebu". Neki podaci ranije su objavljeni u: Vrga, Stoljeće petrinjske likovnosti. Uloga Pjera Križanića u kontekstu hrvatske scene karikaturista protumačena je u: Dulibić, Povijest karikature u Hrvatskoj do 1940., 164-I69.

3 Vrga, Stoljeće petrinjske likovnosti, $4^{2}$. 4

Boris Vrga navodi podatke kako je Križanić „u prvo vrijeme radio kao soboslikarski kalfa kod Albreta Harbicha na Radničkom dolu u Zagrebu, a potom kao soboslikarski pomoćnik kod Ivana Drusanija. Sa ušteđevinom od 80 forinti, uspio se I908. upisati na slikarski odjel Privremene više škole za umjetnost i umjetni obrt, radeći tokom studija honorarno kod raznih molera te crtača i pisaca natpisnih ploča za razne trgovačke i zanatske firme.” Vrga, „Pjer u Zagrebu”, 49.
Privremena viša škola za umjetnost i obrt, buduća Akademija likovnih umjetnosti u Zagrebu, pokrenuta je 1907., a Križanić se upisao 1908. kao student druge generacije. Iste 1908. godine počeo je objavljivati karikature u najvažnijem hrvatskom humorističko-satiričkom časopisu Koprive. Zanimljivo je podsjetiti na kolege s kojima je studirao. Iz prve generacije studenata susretao je, među ostalima, studente koji su ubrzo pokazali talent za karikaturu i već u to doba počeli objavljivati svoje radove. Bili su to Ljudevit Kara (Beč, 1889.- Zagreb, 1973.), Branimir Petrović (Piljenice kraj Kutine, 1888.- Commugny, 1957.) i Slavko Vereš (Vrtlinska kod Čazme, 1887.-London, 1953.). Ova trojica činit će s Križanićem važan dio redakcije popularnih Kopriva koje su pokrenute 1906. Nema sumnje da je na likovnoj akademiji 
profesor Menci Clement Crnčić (Bruck na Muri, 1865.Zagreb, 1930.) bio važan za Križanića u njegovim formativnim godinama, jer je upravo Crnčić imao rafiniranu grafičku kulturu i sklonost prema portretnoj karikaturi (volio je crtati karikature kolega i prijatelja), a povremeno je i objavljivao svoje karikature. Nema mnogo sačuvanih brojeva Kopriva iz 1908., a samo su dva broja sačuvana iz 1909., tako da nemamo mogućnosti vidjeti najranije Križanićeve karikature. Koliko se Križanić tijekom studija posvećivao slikarstvu ostaje gotovo u potpunosti nepoznato. Rijedak je primjer ulja na platnu iz tog razdoblja autoportret nastao između 1908. i 1911. Taj autoportret ne samo da je odraz njegova talenta nego pokazuje i težnju da pronikne u vlastiti karakter, odnosno da uspravnim stavom tijela, stisnutim usnicama i prodornim pogledom izrazi odlučnost i mladenački prkos. (SI.1)

Križanić na kraju nije završio studij na zagrebačkoj likovnoj akademiji jer je „zaključkom profesorskog odbora na sjednici održanoj 6. III. 1912. isključen iz nastave”. ${ }^{5}$ Mogući razlog izbacivanja s akademije pažljivo analizira Boris Vrga te dolazi do zaključka da je razlog bila prije svega Križanićeva politička aktivnost, o kojoj je i sam Križanić pisao: „Meni, kao i mnogima drugima, beše u to vreme glavno zanimanje rušenje Austrije. Rušio sam je gde sam stigao: u školi, u kafani, revolucionarnim napisima po periferijskim tarabama i ostalim diskretnim mestima." 6 Pjer je bio pristalica jugoslavenske ideje, a o tome svjedoči i povijesno zanimljiva fotografija Sastanak hrvatske i srpske nacionalističke omladine u Splitu 1911. na kojoj su Pjer Križanić, Jozo Kljaković, Jerolim Miše, Krešimir Kovačić, Tin Ujević i Dimitrije Mitrinović.

Jugoslavenski orijentiran, Križanić je nakon atentata na Slavka Cuvaja 1912. bio uhapšen zbog sumnje da je pripadao atentatorskoj grupi. Nakon što je pušten iz zatvora, odlazi u Mečenčane. Iz Mečenčana odlazi u Vojvodinu u manastir Grgeteg na Fruškoj gori, gdje je slikao ikonostas korske kapele (nije sačuvan). ${ }^{7}$ U Hrvatsku se vratio 1913. Tijekom te godine šest mjeseci oslikavao je ikonostas crkve Uspenja Bogorodice u Kukuruzarima, a potom je započeo oslikavanje ikonostasa restaurirane crkve u Mečenčanima, mjestu njegova školovanja. ${ }^{8}$ Oslikavanje tog ikonostasa prekinuo je Prvi svjetski rat, jer je Križanić 1915. u Mečenčanima mobiliziran.

\section{RAZDOBLJE \\ PRVOG SVJETSKOG \\ RATA}

Pjer Križanić u Mečenčanima je 1915. mobiliziran u 96. pješačku pukovniju u Karlovcu i poslan na talijanski front, gdje je sudjelovao u bitkama na Soči i rijeci Piavi. Tijekom ljeta 1916. boravi u Ajdovščini, kao i Bogumil Car, koji u svojim sjećanjima na te dane svjedoči o Križanićevoj snalažljivosti i u ratu: „S njim sam se najviše družio. On je divno živio. Nije ništa radio, čuvali su ga kao slikara. Kao običan vojnik bio je udijeljen strojnoj pušci. Tu se pritajio i ugurao k vodičima konja, a kao takav, lako se dodijelio bilo kamo." ${ }^{9}$ Zlatko Šulentić opisao je kako su uz njega bili mobilizirani i Vilko 
Gecan, Vladimir Varlaj i Mirko Uzorinac, a jedan od njihovih zadataka bio je da slikaju strašne prizore stradanja na ratištima prema razglednicama. ${ }^{10}$ Tijekom 1916 . neko vrijeme izdavao je litografski tiskan list Brocak. ${ }^{11} \mathrm{U}$ Karlovcu je Vilku Gecanu i Petru Križaniću nadređeni poručnik dodijelio improvizirani atelijer u kojem su slikali reklamni pano za gostioničara Hafnera ${ }^{12}$. Boris Vrga navodi kako je „ova pano-slika, nazvana ,Pred krčmom', danas u Muzeju grada Karlovca, svojevrsni kuriozum naše umjetnosti: Križanić je učinio karikirani crtež, a Gecan ga je oslikao". ${ }^{13}$ Podaci su iz razdoblja Prvoga svjetskog rata oskudni pa nastavak njegova djelovanja možemo bolje rekonstruirati nakon povratka u Zagreb. (SI. 2)

\section{KRIŽANIĆ \\ U KOPRIVAMA}

Križanić se kretao u krugu književnika, umjetnika i boema okupljenih oko Matoša, provodeći gotovo čitave dane u kavanama u kojima su se okupljala uredništva pojedinih časopisa. ${ }^{14}$ Matoš ga je poticao i na bavljenje karikaturom pa na njegov poticaj objavljuje i svoju prvu karikaturu, književnika Josipa Kosora u zagrebačkim Koprivama (1909.). Iako je neupitno da se Križanić tijekom studiranja na zagrebačkoj likovnoj akademiji kao karikaturist razvijao i mijenjao svoj likovni izraz, danas je teško o tome prosuđivati na temelju malog broja sačuvanih crteža. ${ }^{15}$

Isto.

Križanić, Predgovor zbirci karikatura Kuku Todore.

7

Sačuvana je samo jedna ikona. To je vrijeme kada je Križanić prešao na pravoslavlje i namjeravao se zakaluđeriti. U mladosti se izjašnjavao kao rimokatolik (kršten je kao rimokatolik, pohađao u školi katolički vjeronauk i u zagrebačku likovnu akademiju upisan kao rimokatolik), I9I3. prešao na pravoslavlje, a I920. oženio se u katoličkoj crkvi sv. Blaža u Zagrebu. Postoji dvojba oko njegova prelaska na pravoslavlje, ali treba spomenuti mogućnost da je i u ondašnjem vremenu postojala mogućnost ženidbe katolika i pravoslavaca. Vrga, „Pjer u Zagrebu”, $52-53$.

8

Vrga, Stoljeće petrinjske likovnosti, $2 \mathrm{I5}$.

Car, „Sjećanja i zapisi”, 266.

10

Ivanuša, „Zlatko Šulentić”.

11

Škomac, „Poznati Banijci: Petar Pjer Križanić”.

12

O tome više u: Vrga, „Pjer i Karlovac”, 3I.

13

Vrga, Stoljeće petrinjske likovnosti, 69.

14

Krklec, „Petar Križanić”, 283.

15

Koprive iz I9I0. i I9II. godine nisu sačuvane.

16

„Na frontu sam sa manjim prekidima ostao sve do sloma Austrougarske monarhije. Odmah po slomu postao sam urednik Kopriva do 1922. kada sam prešao u Beograd u Novi list, a 1923. u Politiku." Arhiv za likovne umjetnosti HAZU-a, Zagreb, Kartoteka likovnih umjetnika, Petar Križanić, Autobiografske bilješke.

17

Za list Pokret radio je i kratko vrijeme u razdoblju između I9Io.

i I9I2. Arhiv za likovne umjetnosti HAZU-a, Zagreb, Kartoteka likovnih umjetnika, Petar Križanić.

18

Horvat, „Koprive i prva generacija karikaturista publicista

u Hrvatskoj", 2I.
Razdoblje Križanićevih mladenačkih radova nastalih od 1909. zaključuje se 1915. kada je bio mobiliziran, nakon čega slijede još tri ratne godine. Drugi dio njegova zagrebačkog razdoblja, koje počinje odmah po završetku rata, obilježeno je njegovim već prepoznatljivim rukopisom i plodnom produkcijom sve do 1922., kada odlazi u Beograd. Koprive, najvažniji i najdugovječniji humorističko-satirički tjednik u Hrvatskoj koji je izlazio od 1906. do 1940. postavlja Križanića na mjesto urednika odmah po slomu Austro-Ugarske Monarhije. ${ }^{16}$ Takav položaj mogao je dobiti samo iskusan i vješt karikaturist koji je znao na koji način atraktivno urediti svaki broj časopisa te motivirati suradnike da dobije kvalitetne priloge.

Godine 1919. Križanić je iznimno produktivan te je autor većine crteža u prvih trinaest brojeva. U tom razdoblju najčešći su mu suradnici Slavko Vereš, Tomislav Kolombar i Ivo Režek. Križanić je u Koprivama objavljivao sve do 1922., a u tom razdoblju povremeno je surađivao i u zagrebačkom Savremeniku, da bi potkraj 1921. bio karikaturist, likovni kritičar i korektor u listu Pokret. ${ }^{17}$ Za knjigu Par nas s Parnasa Kreše Kovačića (Zagreb, 1922.) izradio je više portretnih karikatura hrvatskih pisaca (G. Krklec, M. Krleža, D. Domjanić, A. B. Šimić, N. Polić i dr.). Josip Horvat istaknuo je značaj činjenice da je Križanić bio Crnčićev učenik i smatrao da „odatle vjerojatno preciznost i čistoća njegova crteža”. ${ }^{18}$ । doista, njegovi preciznim linijama oblikovani likovi zaustavljeni su u pokretu, u trenutku koji traje, u trenutku koji bi trebao odraziti misao koja dominira likovima i prostorom u kojem se nalaze. Kao portretni karikaturist, nenametljivom gestom, kao i izrazom lica, pogađa bit karaktera karikirane osobe. 


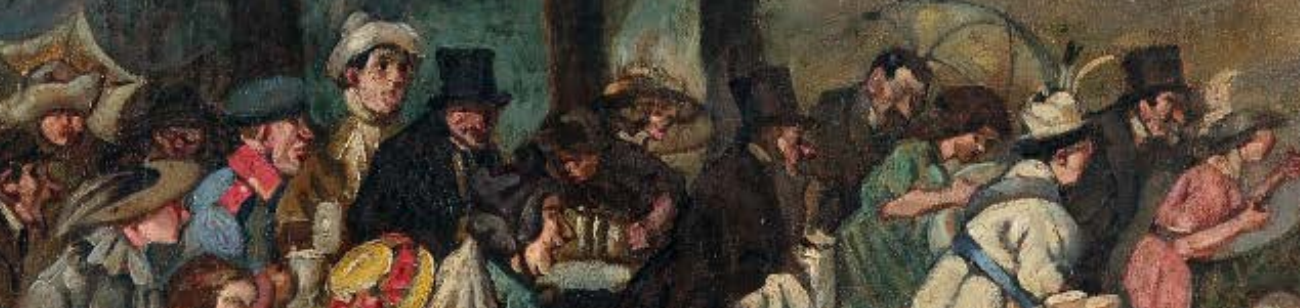

a)

a)

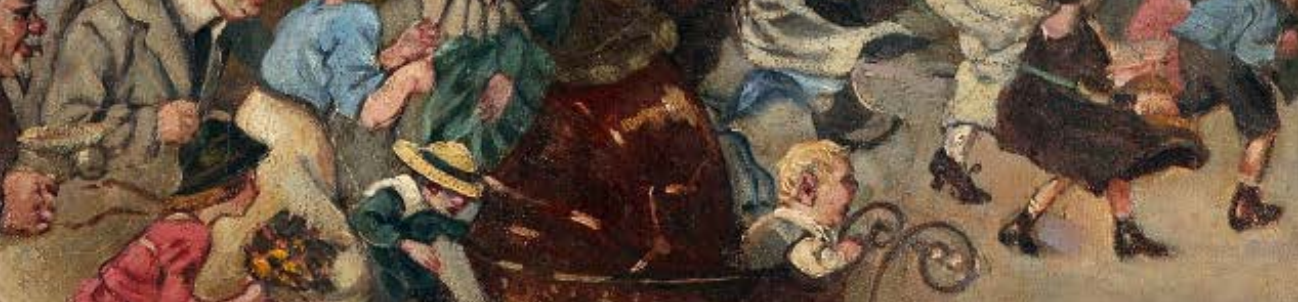

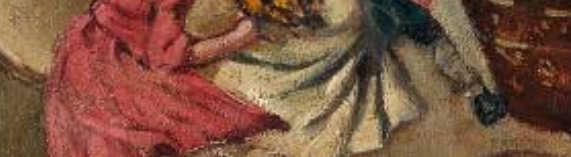
(1) 
Godine 1922., kada se odlučio preseliti u Beograd, dio studentskih radova (zajedno sa studentskim autoportretom u ulju na platnu) ostavio je prijatelju Bogumilu Caru. ${ }^{19}$

\section{LIKOVNI UZORI I KARAKTERISTIKE KRIŽANIĆEVA CRTEŽA}

Križanićevi likovni uzori, prije svega njemački i francuski karikaturisti, vidljivi su u njegovu likovnom rukopisu, a potvrdu nalazimo u njegovu tekstu „O karikaturi” objavljenom 1921. u časopisu Kritika. ${ }^{20}$ Taj tekst na najbolji način otkriva kako shvaća karikaturu, kao i svoje uzore na europskoj sceni. Kao relevantan izvor kvalitetne karikature Križanić navodi minhenski tjednik Simplicissimus: „Bez obzira na njegovo neprijateljsko držanje prema Slavenima i često neukusne ispade specijalno protiv nas, minhenski je Simplicissimus bio izraz najoštrije, najduhovitije i najumjetničkije kritike literarnih njemačkih krugova."21

Simplicissimus je bio najutjecajniji tjednik ne samo Njemačke nego i čitave srednje Europe, a izlazio je u Münchenu od 1896. do 1967.. ${ }^{22}$ Osim vrsnih suradnika koji su objavljivali svoje tekstove, poput Thomasa Manna i Rainera Marije Rilkea, likovne priloge stvarali su poznati autori poput Georgea Grosza, Käthe Kollwitz, Johna Heartfielda, kao i oni manje poznati široj javnosti poput Thomasa Theodora Heinea, Karla Arnolda, Olafa Gulbranssona, Edwarda Thönyja, Bruna Paula, Josefa Benedikta Engla, Rudolfa Wilkea, Ferdinanda von Rezníčeka, Josepha Sattlera i Jeanne Mammen. Kada se promotri dominirajući politički stav Simplicissimusa protiv fašizma i boljševizma, koji se zalagao za radnike i podbadao vlasti tako žestoko da su pojedini autori ili urednici zatvarani, i takav koncept usporedimo s Koprivama, možemo vidjeti kako je redakcija Kopriva vrlo slično reagirala na politička događanja.

Drugi veliki izvor crtačkih uzora Križanić vidi u francuskim karikaturistima, od Daumiera, preko Toulousea Lautreca, do Léandrea, Foraina i Matoševa prijatelja Rouveyerea. ${ }^{23}$ Dobro poznavanje francuskih karikaturista vjerojatno je posljedica druženja s Matošem, koji je tu scenu iznimno dobro poznavao. Čak i pseudonim Pjer, koji je kasnije prihvatio kao svoje ime, dolazi iz francuskog jezika. Matoš je zagrebačke karikaturiste upoznao s tradicijom i tadašnjom scenom francuske karikature koja je njegovala složeniji crtež s gušćom strukturom linija, za razliku od njemačke tradicije koja je bila sklonija jednostavnijim linijama, jasnim formama predmeta, likova i prostora, odnosno stilizaciji koja oblike svodi na temeljne karakteristike. Među francuskim karikaturistima koje Križanić ne spominje u svojem tekstu o karikaturi, a koji su mu mogli biti bliski, treba spomenuti važna imena kao što su Félix Valloton, Jean-Louis Forain, a donekle i Caran D'Ache.

Treća skupina autora koji su utjecali na njegov likovni izraz bili su njegovi kolege zagrebački karikaturisti, počevši od već spomenutog profesora Mencija Clementa Crnčića, do svih koji su se okupljali u redakciji Kopriva, ponajviše Slavka 


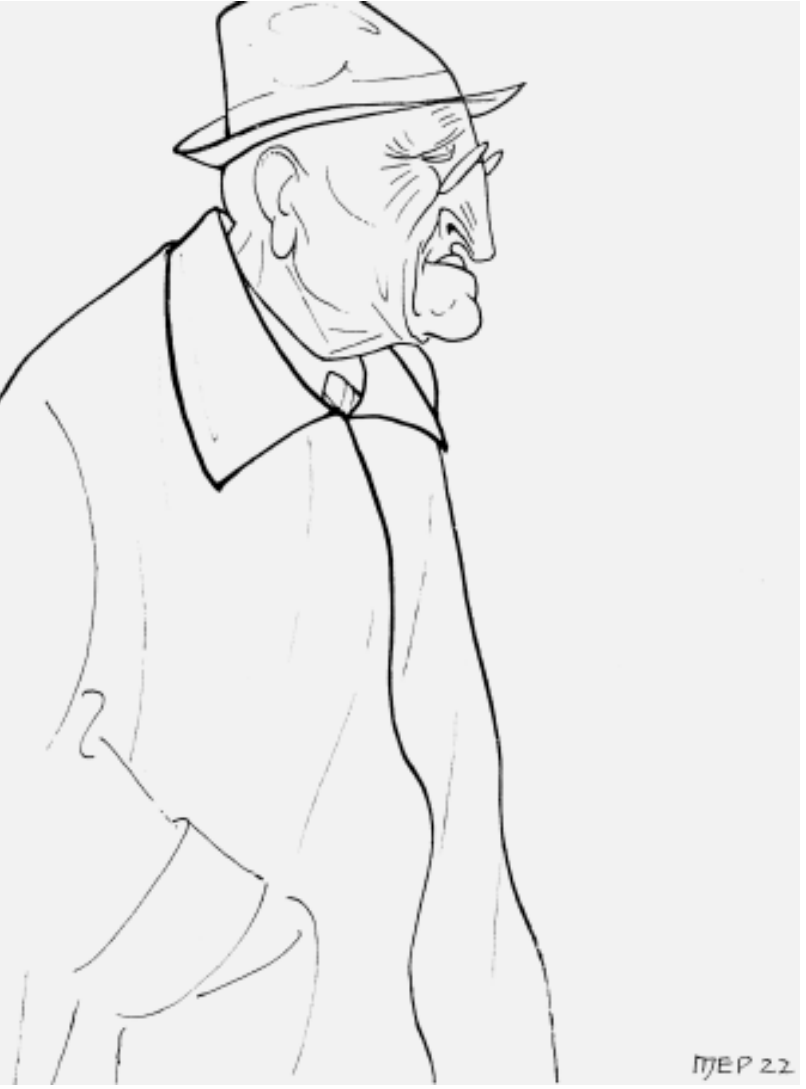

SI. 3 Pjer Križanić, Ivo Ćipiko, 1922., crtež tušem, sign. Pjer 22 (ćirilicom). VI. Boris Vrga / Fig. 4 Pjer Križanić, Ivo Ćipiko, 1922, ink drawing, sign. Pjer 22 (in cyrillic script). Coll. Boris Vrga.

$\uparrow$

19

Podatak dobiven u razgovoru s kolekcionarom dr. Josipom Kovačićem, u Zagrebu 2007.

20

Usp. Križanić, „O karikaturi”.

21

Isto.

22

Koch, Behmer, Grobe Wahrheiten - Wahre Grobheiten - Feine

Striche-Scharfe Stiche.

23

Charles Lucien Léandre (I862.--1934.), Jean-Louis Forain (I852.-I93I.), André Rouveyer (I879.-I962.). Kada Križanić piše o njemačkim i francuskim karikaturistima i uspoređuje njihove karakteristike, ne odaje svoju sklonost pojedinim autorima, već samo pokazuje da dobro poznaje karikaturiste na europskoj sceni. Usp. Križanić, „O karikaturi”.

24

Boris Vrga također je analizirao Križanićev rukopis. Usp. Vrga,

Satirični kroničar vremena.

25

Isto.

26

Tumačenje razlika između portretne i situacijske karikature vidjeti u: Dulibić, Povijest karikature u Hrvatskoj do I94o. godine, II-I4.
Vereša, a potom i Branimira Petrovića, Franje Maixnera, Ive Režeka te Bogumila Cara.

Sve tri navedene grupe autora imale su određeni utjecaj na formiranje Križanićeva pristupa karikaturi ne samo u oblikovnom nego i u sadržajnom smislu te su doprinijela oblikovanju Križanićeva prepoznatljivog likovnog izraza. (SI. 3)

U analizi Križanićeva rukopisa uočljiva je jasna obrisna linija bez suvišnog detaljiziranja. ${ }^{24}$ Sve se svodi na bitne karakteristike u jednakoj mjeri: likove, predmete i prostor. Njegove su kompozicije čiste, uravnotežene i ritmične, a prostor je pojednostavljen i plošan. To pojednostavljivanje prostora nije samo zbog jasnoće poruke, nego se istodobno želi stvoriti odmak od stvarnog prostora, čime se ističe činjenica da je to zapravo (imaginarni) prostor karikature i time daje do znanja da umjetnik doista razumije pravu prirodu medija. Uostalom, to je i sam riječima izvrsno formulirao: „Kao što je karikatura po svojoj tendenciji eliminiranja suvišnih detalja, a potenciranja karakterističnih, produkt više fantazije nego oka, koje je upravo preopterećeno suvišnim detaljima, tako i najbolje karikature nastaju bez prisutnosti modela. Naročito ako je karikaturista dulje vremena živio s predmetom karikature, onda se u fantaziji karikaturiste iskristalizuje čisto duševnim okom gledani lik, bez fizičkih i nebitnih detalja. Tako nastaju djela, koja nam najjednostavnijim tehničkim sredstvima i čudesnom imaginarnom snagom dočaravaju ljude sa njihovim najskrivenijim i najtajnijim osebinama." ${ }^{25} \mathrm{~S}$ obzirom na to da se najčešće izražavao političkom karikaturom, često je spajao elemente portretne i situacijske karikature, jer je predstavljao, odnosno kritički interpretirao djelovanje političara u i apsurdnim situacijama koje izazivaju smijeh. ${ }^{26}$ Osim toga, duhovito je reagirao u svojim karikaturama na događanja u umjetničkim i novinarskim krugovima. Izvrsni su primjeri takvih karikatura Iz Ullrichovog salona (1920.) i Iz novinarskog društva (1919.), obje objavljene u Koprivama. (SI. 4 i 5 )

Ovi Križanićevi radovi dočaravaju nam atmosferu na otvorenjima izložbi ili u kavanama, a istodobno su i karikature stvarnih protagonista, primjerice poznatih zagrebačkih novinara, među kojima su u prvom planu Marija Jurić Zagorka i Krešo Kovačić. Takva karikatura skupine novinara u prostoru kavane duhoviti je povijesni dokument koji mora imati svoje mjesto u povijesti hrvatskog novinarstva. Ova karikatura otvara i načelno pitanje autorstva ideje za nekoliko karikatura. Naime, spomenuti Križanićev prijatelj Krešo Kovačić često je bio autor ideje, odnosno teksta za pojedine karikature nekolicine ondašnjih zagrebačkih karikaturista. Nemamo podataka o njihovoj mogućoj suradnji u tom obliku te stoga ostaje otvorena mogućnost da su neke karikature zajedno osmislili, na zajedničko zadovoljstvo.

Izgleda da je Križanić bio sklon mijenjati crtački način izražavanja, poput nekih drugih produktivnih karikaturista. Naime, ponekad bi crtež riješio samo linijski, ponekad s teškim sjenčanjima i gustim linijskim strukturama, 


\section{Iz Ulrichovog salona.}

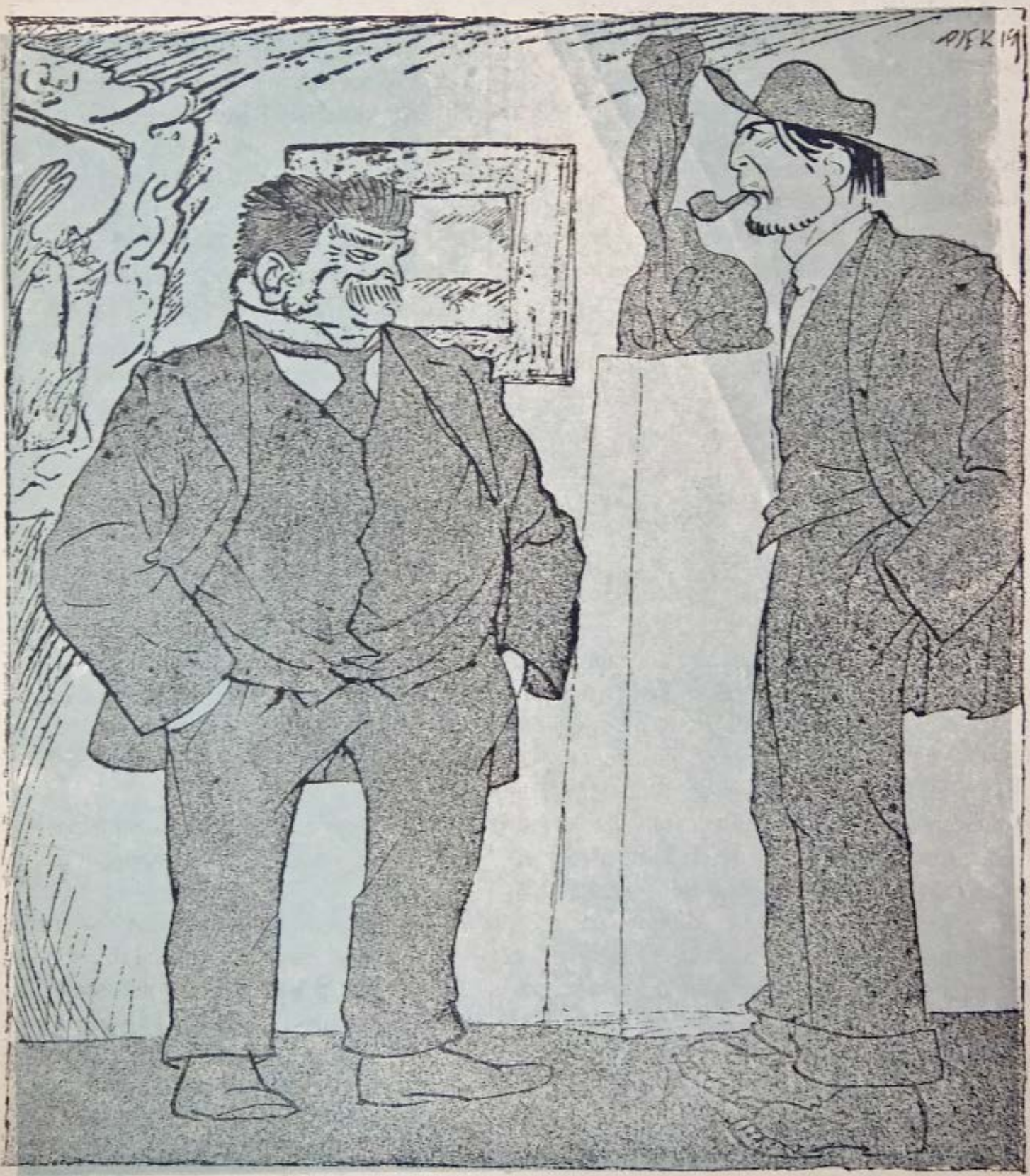

vrednosti*.

- „Ja se čudim gospodin Ulrich, da ste ovu sliku kupili. Zo za mene nema nikakəve

- "E, ali zato ima za autora, koji je za nju dobio 3000 kruna".

SI. 4 Pjer Križanić, Iz Ullrichovog salona (Koprive, 1920., br. 1, 4) / Fig. 4 Pjer Križanić, Iz Ullrichovog salona [From the Ullrich's Salon] (Koprive, 1920, No. I, 4)
SI. 5 Pjer Križanić, Iz novinarskog društva (Koprive 1920. [?]) / Fig. 6 Pjer Križanić, Iz novinarskog društva [From the Society of Journalists] (Koprive 1920, [?]). 
Iz novinarskog društva.

P: Križanić.

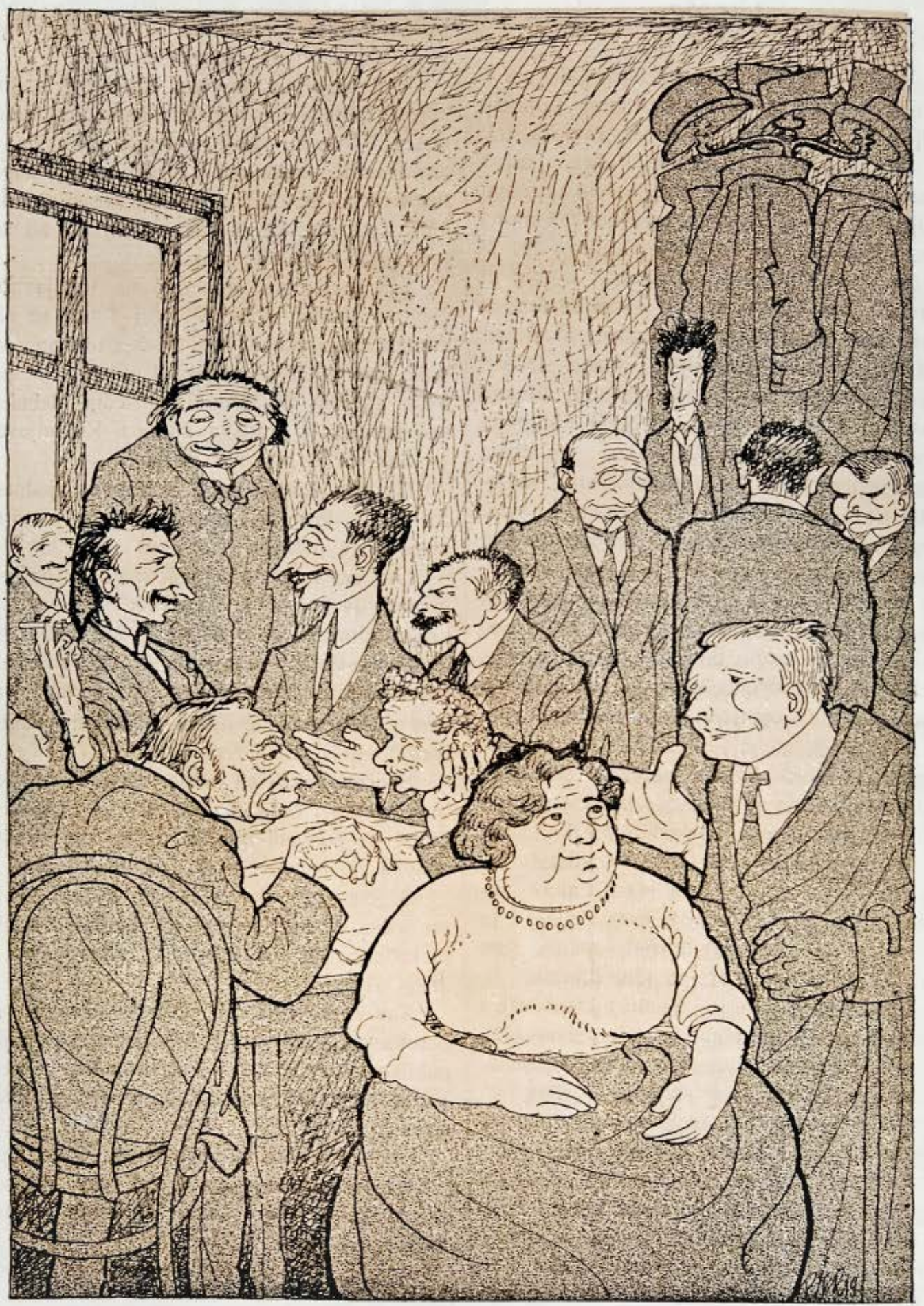

Gospodo sastali stno se, da pretresamo pitanje, koja je zapravo svrha našıga drus̀tva. I poštónisıo došli do nikakvog zaključka, zaključujemo današnju sjednicu i uričen o slijedeću ミ0. veljače 1930. god. 
a ponekad kao da je radio u tehnici linoreza ili drvoreza i tada istaknuo ekspresivnost crteža. Razlog takvom mijenjanju likovnog izraza možemo naći u težnji da ne postane dosadan i predvidljiv, odnosno da se ne ponavlja u uvijek istom likovnom konceptu. U svojim crtežima znao se poslužiti ekspresivnim i nadrealnim elementima, ali ne treba zanemariti da je u međuratnom razdoblju ponekad nacrtao pojedine karikature u čistom art déco stilu. To je značilo stvarati karikature izrazito stiliziranih, a često i izduženih oblika te elegantnih linija, na način koji je bio vrlo popularan u grafičkoj industriji međuratnog razdoblja u čitavom svijetu.

Križanić je majstorski koncipirao situacijske karikature, ponajviše političke, ali ništa slabiji nije bio ni u portretnim karikaturama. Njegovo zagrebačko razdoblje završava spomenutom knjižicom Par nas s Parnasa Krešimira Kovačića, objavljenom 1922., za koju je, uz naslovnicu, načinio deset portretnih karikatura književnika, među kojima možemo izdvojiti izvrsno pogođene likove Gustava Krkleca, Miroslava Krleže i Ljubomira Micića. Ne samo da je izvrsno pogodio portretne karakteristike pojedinog književnika nego je uz karikiranje stvarnog izgleda uspio dočarati i pojedine karaktere izvedene iz specifičnog držanja tijela, crta lica, kose i pogleda. ${ }^{27}$ (SI. $\left.6,7,8\right)$

Križanićeve teme u zagrebačkom razdoblju, posebno kada je riječ o politici, mogu nastajati iz lokalne situacije, ali i obrađivati međunarodnu političku scenu i imati univerzalnu poruku koja je često mirotvorna. Komentiranje ljudske gluposti Križanić nije ograničio samo na političare, o čemu svjedoči izvanredan primjer karikature vjerskih vođa pod naslovom Narodno jedinstvo u Bosni. Tri lika, pravoslavni prota, muslimanski muftija i katolički svećenik, mlate se štapovima na kojima su simboli njihovih vjera te djeluju kao da su u nekom nadnaravnom hipnotičkom borbenom plesu. Duhovitost scene pojačava tekst ispod karikature: „Predstavnici svih triju vjera uzajamnom tolerancijom energično rade na učvršćenju narodnog jedinstva i jugoslavenske ideje." Ovakvim radovima Križanić pokazuje da iznimno dobro zna proniknuti u mentalitet ljudi i karakteristike njihova ponašanja te ih duhovito interpretirati u karikiranom obliku. (SI. 9)

\section{KRIŽANIĆEVA \\ OSTAVŠTINA - DOPRINOS \\ RAZUMIJEVANJU I TOLERANCIJI}

Prema mišljenju onih koji su o Križaniću pisali, njegovim dolaskom u Beograd Srbija je dobila svojeg oca političke karikature. Od 1922. živi u Beogradu i postaje suradnik Novog lista, a od 1923. stalni je karikaturist, povremeno i likovni kritičar Politike. Svoj prvi izbor karikatura objavio je u knjizi Naše muke (Beograd, 1923.), a potom i u mapama Kuku Todore (Beograd, 1926.) i Protiv fašizma (Beograd, 1948., s prilogom o Križaniću V. Ribnikara). Godine 1935. bio je jedan od pokretača te potom i dugogodišnji suradnik beogradskog časopisa Ošišani jež.

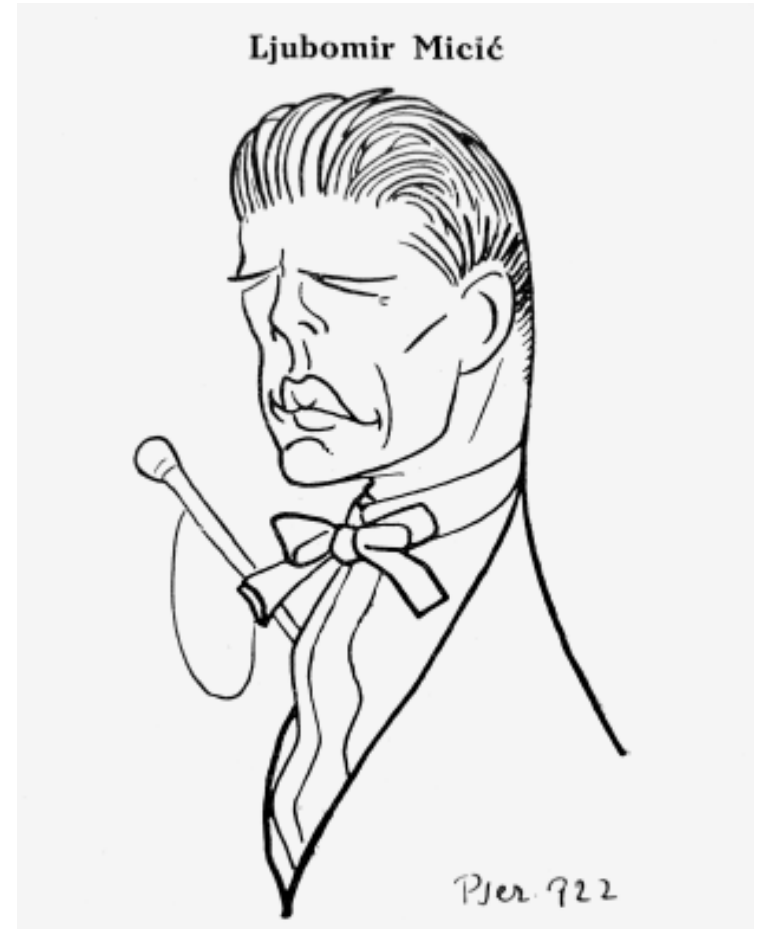

Govorim perfektno licko-krbavski; natucam ponesto $i$ belovarsko-krizevacki; zato izdajem reviju na svim svjet. shim Jezicima, a u njoj pišem lako, da me nijedon narod na soijeí ne razumije...

SI. 6 Pjer Križanić, karikatura Ljubomira Micića (Krešimir Kovačić, Par nas s Parnasa, 1922.) / Fig. 7 Pjer Križanić, the caricature of Ljubomir Micić (Krešimir Kovačić, Par nas s Parnasa, 1922).

$\uparrow$
27 Dunja Fališevac donosi cjelovitu analizu zbirke „parodičko-

karikaturalnih” pjesama Par nas s Parnasa. Fališevac, „Krešimir Kovačić, parodist i karikaturist, pisac feljtona o Parizu, Zagrebu, Hrvatima i Srbima". 


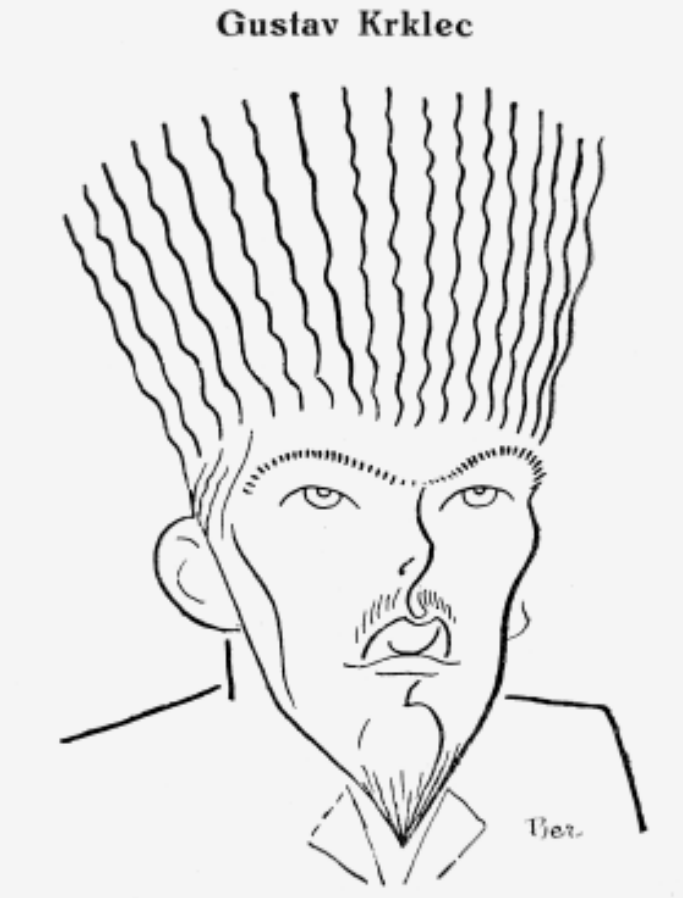

Ja uvjek tordim: „Pravi se pjesnik mora roditia. Dakle, ja sam ispunio glavni uslov za pjesnika; rodio sam se...

SI.7 Pjer Križanić, Karikatura Gustava Krkleca (Krešimir Kovačić, Par nas s Parnasa, Zagreb, 1922.). / Fig. II Pjer Križanić, Karikatura Gustava Krkleca (Krešimir Kovačić, Par nas s Parnasa, Zagreb, I922.).

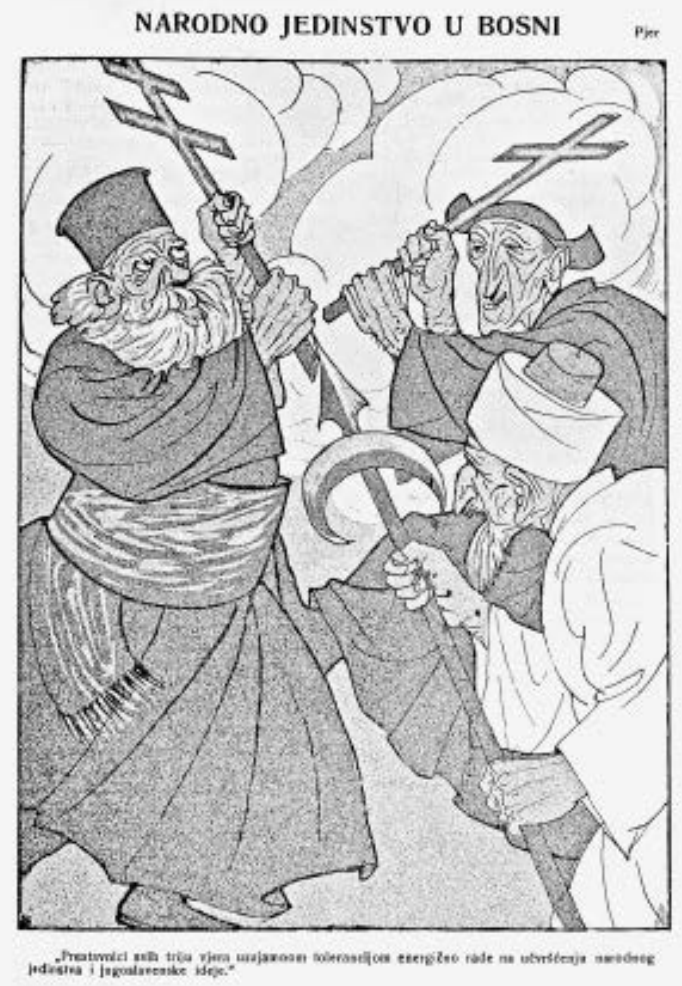

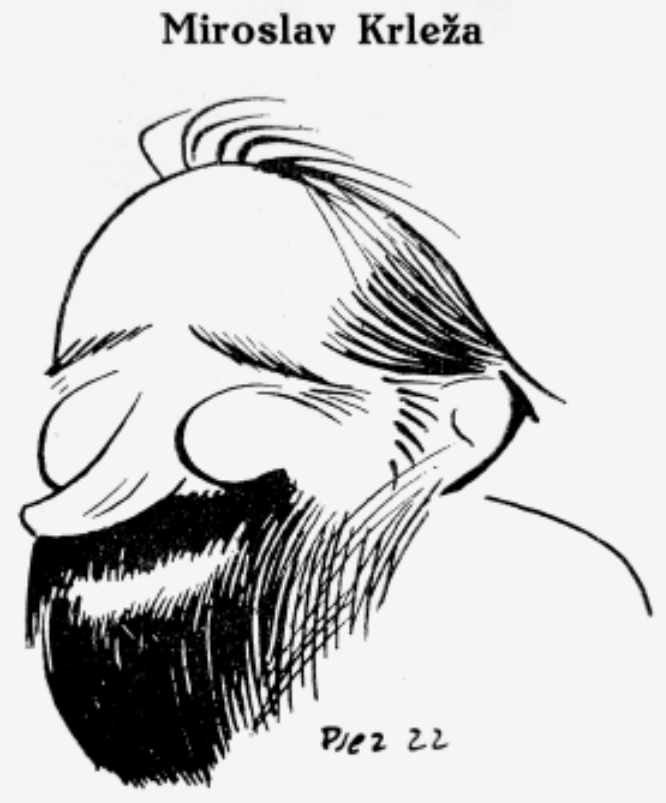

Ja sam vjetar, dižem prah

Zar Vas nije djeco strah?

Sl. 8 Pjer Križanić, karikatura Gustava Krkleca (Krešimir Kovačić, Par nas Parnasa, 1922.) / Fig. 8 Pjer Kržanić, the caricature of Gustav Krklec (Krešimir Kovačić, Par nas Parnasa, 1922) $\leftarrow$

SI. 9 Pjer Križanić, Narodno jedinstvo u Bosni (Koprive, Zagreb 1920., br. 41, naslovnica) / Pjer Križanić, Narodno jedinstvo u Bosni [People's Unity in Bosnia] (Koprive, Zagreb I920, No. 4I, cover) 
Zbog doprinosa novinarstvu, 1941. Križanić je bio izabran za predsjednika Novinarskog udruženja u Beogradu. Drugi svjetski rat proveo je većim dijelom skrivajući se na Zlatiboru, a 1944. pridružuje se partizanima te biva prebačen u Bari u Italiju. ${ }^{28}$ Odmah nakon oslobođenja Beograda 1944. sudjelovao je u ponovnom pokretanju Politike i Ošišanog ježa, a 1945. izabran je za prvog predsjednika Saveza novinara Jugoslavije.

Križanić je umro u Beogradu 1962. Pet godina od njegove smrti, 1967., beogradske Večernje novosti počinju dodjeljivati godišnju nagradu „Pjer” za najbolju novinsku karikaturu. Ni njegov rodni kraj u Hrvatskoj nije na njega zaboravio: od 1981. jedna ulica u Glini nosi ime Pjera Križanića, 1990. godine ondje je obilježena stota godišnjica njegova rođenja, dok se posljednjih godina Igor Mrkalj zalaže se za pokretanje Muzeja karikatura Petra Križanića u Glini. ${ }^{29}$

Križanićev život i djelo je u velikoj mjeri odredilo njegovo dvojno, hrvatsko i srpsko podrijetlo. Poznat je njegov kratki autobiografski tekst iz 1926. u kojem je duhovito opisao djetinjstvo u kojem je od jedne ili druge rodbine za izjašnjavanje Srbinom ili Hrvatom dobivao novac, a kad bi se izjasnio kao Jugoslaven dobivao bi batine. Pišući o sebi zapravo piše o problemu nacionalizma: „Posle rata nastavio sam novinarisanje i karikiranje u Zagrebu, gde me mnogi smatrahu velikosrpskim centralistom, i u Beogradu, gde mi opet predbacuju hrvatski separatizam. Ta se situacija nije izmenila ni sporazumom onih u Zagrebu s onima u Beogradu. Među ostalim sporazumeli su se i u tome da me ni jedan ni drugi ne priznaju svojim." ${ }^{30}$ Križanićeve karikature, koje je sam smatrao „sredstvom političke i socijalne borbe”, u kojima je oštro reagirao na negativnosti društvenog i političkog života, desetljećima nakon objavljivanja ne gube na svojoj aktualnosti. Osim toga, ne treba zaboraviti da je u međuratnom razdoblju, a i poslije Drugog svjetskog rata, Križanić utjecao na brojne karikaturiste ne samo u Hrvatskoj i Srbiji nego i drugim dijelovima onodobne države. Uravnoteženim odnosom preciznog i širokoj publici razumljivog crteža te jasne kompozicije i duhovite, često politički snažne ideje ili pak univerzalnih humanističkih načela, bio je uzorom mnogima koji su se bavili karikaturom.

Sve dok se vraćamo ostavštini Pjera Križanića, to znači da smo svjesni nasljeđa pojedinaca koji su se zalagali za pravednije i bolje društvo, koji su bili protiv korupcije i licemjerja te protiv rata. Također, znači i to da nam ovakvi pojedinci još uvijek nešto predstavljaju, da njihova djela imaju svoju likovnu, kulturnu i povijesnu vrijednost. Napokon, znači i da postoji razumijevanje da Križanićeva ostavština pripada podjednako i hrvatskoj i srpskoj kulturi te da je ujedno zanimljiva izvan naših granica, upravo u brojnim univerzalnim porukama koje su i danas aktualne. ${ }^{31}$ (SI. 10)

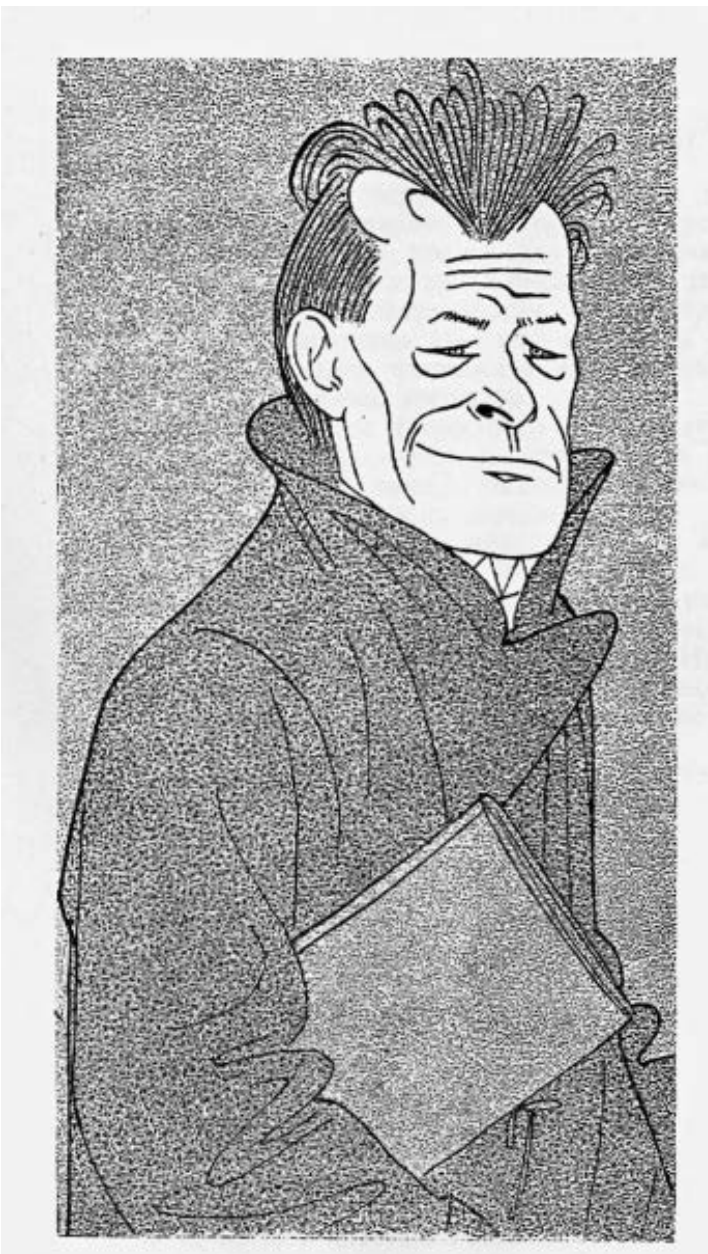

ПЕТАР КРИЖАНИЋ:

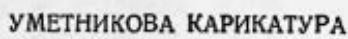

SI. 10 Pjer Križanić, Umetnikova karikatura [autoportret] (Pokret, Beograd, br. 17-18, 1924., 283) / Fig. II Pjer Križanić, Umetnikova karikatura [Artist's Caricature, autoportrait] (Pokret, Beograd, No. I7-I8, 1924, 283).

$\uparrow$

\section{8}

Druženje Pjera Križanića i Joze Kljakovića u Splitu I9II. prilikom sastanka srpske i hrvatske nacionalističke omladine nastavilo se I944. kada su zajedno boravili nedaleko od Barija, u jednoj vili koja je bila svojevrstan partizanski štab. Te njihove susrete tijekom I944. Jozo Kljaković usputno spominje u nekoliko navrata u svojim memoarima. Kljaković, U suvremenom kaosu, 232, 238, $24 \mathrm{I}$. 29

Mrkalj, „Petar Križanić, biografska bilješka”.

30

Križanić, Pogovor zbirci karikatura Kuku Todore. 31

Rezultati istraživanja o Pjeru Križaniću predstavljeni su na znanstvenom skupu „Umjetnička baština Srba u Hrvatskoj”, održanom 6. studenoga 20I8. u organizaciji SKD-a Prosvjeta u Zagrebu. Ovaj je rad sufinancirala Hrvatska zaklada za znanost projektom IP-20I8-oI-9364 Umjetnost i država u Hrvatskoj od prosvjetiteljstva do danas. 


\section{POPIS LITERATURE / BIBLIOGRAPHY}

Arhiv za likovne umjetnosti HAZU-a, Zagreb, Kartoteka likovnih umjetnika, Križanić, Petar.

Bojičić, Radivoje. Petar Križanić Pjer, Beograd: Službeni glasnik, 2010.

Car, Bogumil. „Sjećanja i zapisi”. U: Bogumil Car, ur. Zdravko Mihočinec, Zagreb: Art Magazin Kontura, 2010.

Dulibić, Frano. Povijest karikature u Hrvatskoj do 1940. godine, Zagreb: Leykam International, 2009.

Fališevac, Dunja. „Krešimir Kovačić, parodist i karikaturist, pisac feljtona o Parizu, Zagrebu, Hrvatima i Srbima”, 15 dana, br. 3 (2003.): 21-23.

Horvat, Josip. „Koprive i prva generacija karikaturista publicista u Hrvatskoj”, Novinar, br. 1 (1964.).

Ivanuša, Dolores. „Zlatko Šulentić”, Karlovački tjednik, br. 45 (1968.), 8.

Kljaković, Jozo. U suvremenom kaosu. Uspomene i doživljaji. Zagreb: Matica hrvatska, 2011.

Koch, Ursula E., Behmer, Markus, ur. Grobe Wahrheiten - Wahre Grobheiten - Feine Striche - Scharfe Stiche. Jugend, Simplicissimus und andere Karikaturen-Journale der Münchner „Belle Epoque” als Spiegel und Zerrspiegel der kleinen wie der großen Welt, katalog istoimene izložbe. München: Institut für Kommunikationswissenschaft der Ludwig-Maximilians-Universität. 1996.

Kovačić, Krešimir. Par nas s Parnasa. Zagreb: Jugoslovenska štampa d.d., 1922.

Križanić, Pjer. [Predgovor zbirci karikatura]. U: Kuku Todore. Karikature. Beograd: Narodna misao, 1927.

Križanić, Pjer. „O karikaturi”, Kritika, br. 3 (1921.), 104-105.

Krklec, Gustav. „Petar Križanić”, Pokret (Beograd), br. 17-18 (1924.), 283-284.

Mrkalj, Igor. „Petar Križanić, biografska bilješka”, Prosvjeta, br. 128/129 (2015.), 47.

Radosavljević, Marija. Pjer Križanić, kroničar jednog vremena, katalog izložbe. Novi Sad: Spomen zbirka Pavla Beljanskog, 2013.

Škomac, Jovo. „Poznati Banijci: Pjer Križanić”, 21. veljače 2016. Banija Online. https://banija.rs/poznati-banijci/15305-poznati-banijcipetar-pjer-krizanic.html (pristupljeno 19. travnja 2021.).

Vrga, Boris. „Pjer i Karlovac”, Prosvjeta, br. 140 (2017.), 30-32.

Vrga, Boris. „Pjer u Zagrebu. Nepoznanice, dileme i kontroverze”, Prosvjeta, br. 146-147 (2018.), 48-55.

Vrga, Boris. Satirični kroničar vremena. Petar Križanić Pjer (katalog izložbe). Zagreb: SDK Prosvjeta, 2017.

Vrga, Boris. Stoljeće petrinjske likovnosti. Petrinja: Hrvatski dom Petrinja, Galerija „Krsto Hegedušić i suradnici”, 2002. 